\title{
15 An Organocatalytic Michael reaction study between phenyl acetaldehyde and nitrostyrene
}

\author{
Gandolfi Donadío, Lucía; ${ }^{\dagger}$ Galetti, Mariana A.; ${ }^{\dagger}$ Giorgi, Gianluca; ${ }^{\ddagger}$ Comin, Maria J. *,† \\ ${ }^{\dagger}$ Centro de Investigación y Desarrollo en Química, Instituto Nacional de Tecnología Industrial (INTI), San \\ Martín, B1650WAB, Argentina. ${ }^{\ddagger}$ Dipartimento di Biotecnologie, Chimica \& Farmacia, Università di Siena, Italy \\ *e-mail corresponding author: jcomin@inti.gob.ar
}

Keywords: organocatalysis; Michael addition; phenyl acetaldehyde

\section{INTRODUCTION}

Organocatalytic Michael addittion has been intensively studied in recent years and provides Michael adducts in a highly stereoselective way. We were interested in developing a simple and stereocontrolled route to 3,4-diphenyl substituted pyrrolidines, that are structural motifs found in many biologically active compounds, using a Michael reaction between nitrostyrenes and benzylic aldehydes as the key step.

Extensive studies on the organocatalyzed Michael reaction between nitroalkenes and aliphatic aldehydes were conducted showing a high syn diastereselection according to Seebach's model. ${ }^{1}$ However, only four examples using a-unsubstituted benzylic aldehydes have been reported and they showed a relative low syn diasteroselectivity. ${ }^{2}$ Since the higher acidity of the a protons of benzylic aldehydes relative to aliphatic ones could affect the reaction mechanism, we decided to examine and optimize the diastereochemical outcome of this process. Herein we report our results concerning diastereoselective Michael reaction between phenylacetaldehyde and nitrostyrene.

\section{RESULTS AND DISCUSSION}

Primarily, a variety of solvents, secondary amines and catalyst concentrations were screened. The best result was obtained using toluene as solvent in presence of $20 \% \mathrm{~mol}$ of pyrrolidine and a 0.5 fold excess of aldehyde.

Scheme 1. Model Reaction.
$\mathrm{H}^{\mathrm{O}} \mathrm{Ph}+{ }_{\mathrm{Ph}} \mathrm{F}^{\mathrm{NO}_{2}}$

$1(0.45 \mathrm{mmol}) \quad 2(0.3 \mathrm{mmol})$

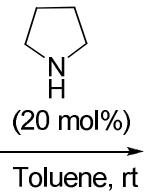

Toluene, rt<smiles>O=CC(c1ccccc1)C(C[N+](=O)[O-])c1ccccc1</smiles>

3
$d r=98: 2$
The reaction yielded a clean product with high conversion and diastereselection. ${ }^{1} \mathrm{H}$ NMR data of the major diastereomer obtained was in accordance with the already described for the syn adduct. ${ }^{2}$ The relative configuration of the major isomer of $\mathbf{3}$ was unambiguously determined by X-ray diffraction and surprisingly revealed to be anti (Figure 1).
In order to understand this result, we monitored the Michael stoichiometric reaction by ${ }^{1} \mathrm{H}$ NMR under anhydrous conditions. The major species observed was the product enamine with only a maximum $\mathrm{ca}$. $20 \%$ of cyclobutane that is typically observed as a major intermediate with aliphatic aldehydes ${ }^{3}$. Moreover, when we tried the reaction using triethylamine instead of pyrrolidine we obtained 3 with the same diastereomeric ratio, suggesting a coexisting mechanism via the enolate.

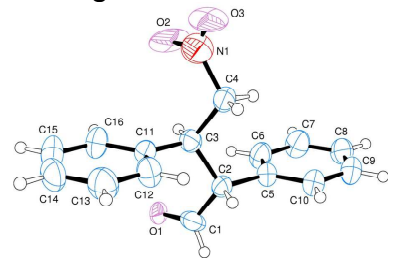<smiles>O=CC(c1ccccc1)C(C[N+](=O)[O-])c1ccccc1</smiles>

Figure 1. X-ray structure of 3

\section{CONCLUSION}

The organocatalized Michael addition of phenyl acetaldehyde to nitrostyrene was studied. The antiadduct was obtained in high diastereoselectivity contrary to Seebach's topological rule. Two types of mechanisms could be active, one involving an enolate, and other an enamine as reactive nucleophiles. In addition, the Michael adduct obtained can easily epimerize to the more stable anti product.

\section{ACKNOWLEDGEMENTS}

This work was supported by CONICET and INTI.

\section{REFERENCES}

${ }^{1}$ Seebach, D.; Golínski, J. HCA, 1981, 64, 1413-1423.

2 (a) Laars, M.; Ausmees, K.; Uudsemaa, M.; Tamm, T.; Kanger, T.; Lopp, M. J. Org. Chem. 2009, 74, 3772-3775. (b) Andrey, O.; Alexakis, A.; Tomassini, A.; Bernardinelli, G. Adv. Synth. Catal. 2004, 346, 1147-1168. (c) Alza, E.; Pericãs, M. Adv. Synth. Catal. 2009, 351, 3051-3056. (d) Zhao, G.-L.; Xu, Y.; Sundén, H.; Eriksson, L.; Sayah, M.; Córdova, A. Chem. Commun. 2009, 734-735.

${ }^{3}$ (a) Burés, J.; Armstrong, A.; Blackmond, D. G. J. Am. Chem. Soc. 2011, 133, 8822-8825. (b) Patora-Komisarska, K.; Benohoud, M.; Ishikawa, H.; Seebach, D.; Hayashi, Y. HCA, 2011, 94, 719-745. (c) Sahoo, G.; Rahaman, H.; Madarász, A.; Pápai, I.; Melarto, M.; Valkonen, A.; Pihko, P. M. Angew. Chem. Int. Ed. 2012, 51, 13144-13148. 